Jurnal Dinamika Sosial Ekonomi Vol.22 No.1, Juni 2021 : 33-45

ISSN 1411-593X (print); ISSN 2721-3137 (online)

\title{
Pengaruh Kompensasi Kompetensi dan Motivasi Terhadap Kinerja Karyawan PTPN IX Kebun Jollong Pati
}

\section{The Effect of Compensation for Competence and Motivation on Employee Performance at PTPN IX Jollong Pati Farm}

\author{
Awang Madu Rangin*, Siti Hamidah, Nanik Dara Senjawati \\ Progam Studi Agribisnis Fakultas Pertanian Universitas Pembangunan Nasional \\ "Veteran" Yogyakarta \\ Jalan SWK 104, Kabupaten Sleman, Yogyakarta, Indonesia \\ *Email korespondensi: maduranginawang@ gmail.com
}

Diterima tanggal : 19 Februari 2021 ; Disetujui tanggal : 2 Maret 2021

\begin{abstract}
The aimed of this reseach are 1) To know the level of Compensation, Competence, Motivation, and Employee Peformance in the Estate Coffee maintenance section at PTPN IX Jollong Estate Pati, 2) Analyze compensation, competence, and motivation influence to Permanent Employee Peformance in the Coffee Estate maintenance section at PTPN IX Jollong Estate Pati directly and indirectly. The basic reseach method used descriptive method and implemented by case study. Data collection methods using observation, interviews and documentation. The respondent retrieval method used is a census, by using all members of the population of 34 permanent employees in the coffee estate maintenance division. Method of data analysis and hypotheses using path analysis. The results of analized showed that 1) Compensation, competence, motivation, and performance of the employees of the coffee estate maintenance section of PTPN IX Jollong Estate Pati were in the high enough category. 2) The variable of compensation, competence, and motivation influenced directly and indirectly to employee peformance in the garden maintenance section at PTPN IX Jollong Estate Pati. The total of direct and indirect effect with a large influence 0.674, the total directly effects with a large influence 0.490 and the indirect effect with a large influence 0.184.
\end{abstract}

Keywords: compensation, competence, motivation and employee performance

\begin{abstract}
ABSTRAK
Tujuan dari penelitian ini adalah 1) mengetahui tingkat kompensasi, kompetensi, motivasi, dan kinerja karyawan tetap pada bagian pemeliharaan Kebun Kopi PTPN IX Kebun Jollong Pati, 2) menganalisis pengaruh langsung dan tidak langsung kompensasi, kompetensi dan motivasi terhadap kinerja karyawan tetap pada bagian pemeliharaan Kebun Kopi PTPN IX Kebun Jollong Pati. Metode dasar yang penelitian ini adalah metode deskriptif dan dilaksanakan dengan metode studi kasus. Untuk metode pengumpulan data menggunakan observasi, wawancara dan dokumentasi. Metode pengambilan respoden yang digunakan adalah sensus yakni
\end{abstract}


dengan menggunakan seluruh anggota populasi pada karyawan tetap bagian pemeliharaan kebun kopi yang berjumlah 34 karyawan. Teknik analisis data dan pengujian hipotesis yang digunakan dalam penelitian ini adalah metode deskriptif dan analisis jalur. Hasil penelitian menunjukkan bahwa :1) Kompensasi, kompetensi, motivasi, dan kinerja pada karyawan bagian pemeliharaan kebun PTPN IX Kebun Jollong Pati termasuk dalam kategori cukup tinggi. 2) Kinerja dipengaruhi kompensasi, kompetensi, dan motivasi secara langsung dan tidak langsung. Total pengaruh langsung dan tidak langsung adalah sebesar 0,674 dimana terdiri dari total pengaruh langsung sebesar 0,490 dan pengaruh secara tidak langsung sebesar 0,184 .

Kata Kunci: kompensasi, kompetensi, motivasi dan kinerja karyawan

\section{PENDAHULUAN}

Dewasa ini persaingan dalam dunia bisnis semakin ketat. Perusahaan dituntut untuk mampu bersaing dengan para pesaingnya. Faktor penting dalam mendukung keberhasilan suatu perusahaan adalah sumber daya manusia. Hal ini karena sumber daya manusia merupakan pelaku dari keseluruhan kegiatan yang berjalan di dalam perusahaan mulai dari tingkat perencanaan sampai dengan evaluasi yang mampu memanfaatkan sumber daya yang dimiliki oleh perusahaan tersebut. Keberadaan sumber daya manusia di dalam suatu perusahaan memegang peranan sangat penting. Tenaga kerja memiliki potensi yang besar untuk menjalankan aktivitas perusahaan. Potensi setiap sumber daya manusia yang ada dalam perusahaan harus dapat dimanfaatkan dengan sebaik-baiknya sehingga perusahaan akan tetap mampu bersaing di dunia bisnis yang semakin ketat ini.

Kinerja penting dalam perusahaan karena pencapaian tujuan perusahaan sangat dipengaruhi oleh kinerja karyawan. Kinerja ini sendiri ialah suatu hasil kerja secara kualitas dan kuantitas yang dicapai baik oleh sekelompok orang maupun individu yang melaksanakan tugasnya sesuai dengan tanggung jawab yang telah diberikan. Kinerja karyawan dapat ditingkatkan dengan cara melakukan beberapa cara yang sesuai dengan situasi dan kemampuan perusahaan, diantaranya adalah dengan memberikan kompensasi kepada karyawannya. Kompensasi merupakan semua bentuk pembayaran atau hadiah yang diberikan kepada karyawan terkait dengan apa yang telah dikerjakan oleh karyawan tersebut (Dessler, 2009). Kompensasi mempengaruhi kinerja karyawan. Pemberian kompensasi kepada 
karyawan perlu diperhatikan. Kompensasi harus memiliki dasar yang kuat, benar dan adil. Apabila kompensasi dirasakan tidak adil maka akan menimbulkan rasa kecewa kepada karyawan, sehingga kinerja karyawan dapat menurun bahkan karyawan akan meninggalkan perusahaan. Oleh karena itu agar dapat mempertahankan karyawan, maka program kompensasi dibuat sedemikian rupa sehingga karyawan yang berpotensi akan merasa dihargai dan bersedia untuk bertahan di perusahaan.

Selain kompensasi, kompetensi juga berpengaruh terhadap kinerja karyawan dalam suatu perusahaan. Menurut Edison, dkk (2016), kompetensi adalah kemampuan individu untuk melaksanakan suatu pekerjaan dengan benar dan memiliki keunggulan yang didasarkan pada hal-hal yang menyangkut pengetahuan (knowledge), keahlian (skill), dan sikap (attitude).Semakin tinggi kompetensi yang dimiliki oleh karyawan, semakin tinggi pula tingkat kinerja karyawan tersebut. Dalam meningkatkan kinerja karyawan, motivasi juga mempengaruhi kinerja karyawan di dalam perusahaan. Motivasi menurut Ranupandojo dan Husnan (2000) dalam Priyono (2007) adalah proses mempengaruhi seseorang agar melakukan sesuatu yang diinginkan. Motivasi diperlukan untuk meningkatkan kinerja karyawan salah satunya adalah pemenuhan kebutuhan. Dengan terpenuhinya kebutuhan tersebut maka karyawan akan bekerja dan melaksanakan tugasnya dengan baik, sehingga pekerjaan yang dilaksanakan dapat mencapai bahkan melampaui target yang sudah direncanakan.

PTPN IX Kebun Jollong memiliki tenaga kerja yang berjumlah 181 karyawan. PTPN IX Kebun Jollong Pati adalah perusahaan yang bergerak di bidang perkebunan, yakni kopi sebagai komoditas utamanya. PTPN IX Kebun Jollong Pati adalah adalah perusahaan terbesar dan tertua yang ada di Kabupaten Pati. Untuk mempertahankan eksistensi produk kopi, maka perusahaan membuat standar yang bertujuan supaya produk kopinya dapat bersaing dan lebih bisa diterima pasar karena sudah sesuai standar. Untuk mempertahankan produk agar sesuai standar yang sudah ditetapkan, maka PTPN membuat SOP dimana tujuan SOP tersebut untuk membuat karyawan agar mampu mengkhasilkan produk sesuai standar. Hal yang membuat berbeda karyawan pada PTPN IX Kebun Jollong 
Jurnal Dinamika Sosial Ekonomi, 22 (1) : 33-45

dengan karyawan yang bekerja di perusahaan yakni UMKM, adalah pada PTPN IX Kebun Jollong Karyawan dituntut untuk mampu bekerja sesuai SOP sehingga nantinya produk yang dihasilkan pun sesuai standar.

Kinerja karyawan pada PTPN IX Kebun Jollong Pati mengalami penurunan Pada 2019 produksi kopi terjadi penurunan. Hal ini dikarenakan masih kurangnya perawatan terutama pada pemangkasan tanaman kopi. Pemangkasan kopi ini bertujuan untuk mempertahankan ketinggian tanaman untuk memudahkan perawatan atau pemeliharaan dan panen. Kinerja pada suatu perusahaan khususnya pada PTPN IX Kebun Jollong berkaitan erat dengan adanya sumberdaya manusia. Kinerja karyawan PTPN IX Kebun Jollong sangat dipengaruhi oleh kompensasi, kompetensi, dan motivasi. Kompensasi yang ada di PTPN IX Kebun Jollong tergolong kurang. Berdasarkan observasi, menurut karyawan bagian pemeliharaan kebun PTPN IX Kebun jollong, gaji karyawan yang sudah sesuai dengan UMK yang berlaku saat ini, namun untuk upah lembur masih belum memuaskan menurut karyawan. Padahal, kompensasi yang diberikan mempengaruhi kinerja karyawan. Semakin baik kompensasi, semakin baik pula motivasi dan kinerja karyawan. Untuk kompetensi, kualitas sumberdaya manusia di PTPN IX Kebun Jollong masih tergolong rendah. Hal ini karena sebagian besar karyawan PTPN IX Kebun Jollong adalah lulusan SD dan SMP.

Kompetensi yang rendah ini mengakibatkan apabila terjadi suatu permasalahan/ kasus, karyawan hanya bekerja menunggu perintah pemimpin/ mandor saja. Motivasi yang ada di PTPN IX Kebun Jollong tergolong cukup rendah, hal ini dapat dilihat dari semangat kerja karyawan yang cukup rendah dalam menyelesaikan tugasnya. Untuk kinerja karyawan pada PTPN IX Kebun Jollong mengalami penurunan. Penurunan ini terjadi karena perawatan tanaman kebun yang kurang, terutama pada bagian pemangkasan tanaman. Hal inilah yang menyebabkan produktivitas tanaman berkurang sehingga hasil panen pun berkurang. Hasil panen kopi tersebutlah yang mengindikasikan bahwa kinerja karyawan menurun. Berdasarkan uraian sebelumnya, penelitian ini bertujuan: 1) mengetahui tingkat kompensasi, kompetensi, motivasi, dan kinerja karyawan tetap pada bagian pemeliharaan Kebun Kopi PTPN IX Kebun Jollong Pati, 2) 
menganalisis pengaruh langsung dan tidak langsung kompensasi, kompetensi dan motivasi terhadap kinerja karyawan PTPN IX Kebun Jollong Pati.

\section{METODE PENELITIAN}

Metode yang digunakan dalam penelitian ini adalah metode studi kasus dan jenis penelitian yang digunakan adalah deskriptif. Jenis data yang digunakan adalah data primer yang diperoleh dari wawancara, observasi dan pemberian kuesioner kepada responden. Data sekunder yang diperoleh melalui literatur dan data perusahaan. Responden yang digunakan pada penelitian berjumlah 34, yang dimana responden dipilih dengan metode sensus yakni seluruh karyawan tetap bagian pemeliharaan kebun kopi PTPN IX Kebun Jollong Pati. Lokasi penelitian berada pada PTPN IX Kebun Jollong Pati, Jawa Tengah. Alasan peneliti memilih PTPN IX Kebun Jollong Pati karena PTPN IX Kebun Jollong Pati adalah perusahaan terbesar dan tertua yang memproduksi kopi dari hulu sampai hilir. Metode analisis data yang digunakan adalah analisis deskriptif dan analisis jalur.

\section{HASIL DAN PEMBAHASAN}

\section{Kompensasi}

Pada penelitian ini penulis membuat beberapa pertanyaan yang dibuat berdasarkan beberapa dimensi variabel kompensasi yaitu dimensi normatif dan dimesi kebijakan. Analisis yang digunakan untuk variabel kompensasi adalah analisis deskriptif, yang bertujuan untuk mendeskripsikan persepsi responden yang diteliti dalam bentuk distribusi frekuensi dan persentase. Berikut kategori pada variabel kompensasi yang digunakan dalam penelitian ini.

Tabel 1. Kategori Variabel Kompensasi

\begin{tabular}{ccc}
\hline Kategori & Skor & $\begin{array}{c}\text { Persentase } \\
(\mathbf{\%})\end{array}$ \\
\hline Rendah & $12,00-21,00$ & $25,00-43,75$ \\
Kurang Tinggi & $21,01-30,01$ & $43,76-62,51$ \\
Cukup Tinggi & $30,02-39,02$ & $62,52-81,27$ \\
Tinggi & $39,03-48,00$ & $81,28-100,00$ \\
\hline
\end{tabular}

Sumber: Analisis Data Primer (2020) 
Jurnal Dinamika Sosial Ekonomi, 22 (1) : 33-45

Tabel 2. Deskriptif Variabel Kompensasi

\begin{tabular}{cccc}
\hline Dimensi & Jumlah Skor & Skor maksimal & Persentase (\%) \\
\hline Normatif & 15,12 & 24 & 63,0 \\
Kebijakan & 15,00 & 24 & 62,5 \\
Total & 30,12 & 48 & 62,7 \\
\hline
\end{tabular}

Sumber: Analisis Data Primer (2020)

Pada tabel 1, diketahui bahwa variabel kompensasi pada PTPN IX Kebun Jollong Pati termasuk ke dalam kategori cukup sesuai. Hal ini dapat dilihat pada jumlah skor adalah sebesar 30,12 dengan persentase sebesar 62,7\% yang termasuk dalam kategori cukup tinggi dimana berdasarkan interval skor yang dibuat yakni masuk dalam rentang 62,52 - 81,27. Artinya kompensasi pada PTPN IX Kebun Jollong Pati sudah dirasa cukup bagi para karyawannya, khususnya pada karyawan bagian pemeliharaan kebun. Hal tersebut sejalan dengan penelitian Nugraha dan Tjahwati (2017) bahwa terdapat pengaruh yang signifikan dan positif antara kompensasi dengan kinerja karyawan. Hal tersebut didukung dengan pernyataan oleh Fikri, dkk (2018) menemukan bahwa kompensasi berpengaruh positif dan signifikan terhadap kinerja karyawan.

\section{Kompetensi}

Pada penelitian ini penulis membuat beberapa pertanyaan yang dibuat berdasarkan beberapa dimensi variabel kompetensi yaitu dimensi pengetahuan (knowledge), keahlian (skill), dan sikap (attitude). Analisis yang digunakan untuk variabel kompetensi adalah analisis deskriptif, yang bertujuan untuk mendeskripsikan persepsi responden yang diteliti dalam bentuk distribusi frekuensi dan persentase. Berikut kategori pada variabel kompensasi yang digunakan dalam penelitian ini.

Tabel 3. Kategori Variabel Kompetensi

\begin{tabular}{ccc}
\hline Kategori & Skor & $\begin{array}{c}\text { Persentase } \\
(\boldsymbol{\%})\end{array}$ \\
\hline Rendah & $21,00-36,75$ & $25,00-43,75$ \\
Kurang Tinggi & $21,01-52,51$ & $43,76-62,51$ \\
Cukup Tinggi & $52,52-68,27$ & $62,52-81,27$ \\
Tinggi & $62,28-84,00$ & $81,28-100,00$ \\
\hline
\end{tabular}

Sumber: Analisis Data Primer (2020) 
Rangin, et.al, Pengaruh Kompensasi Kompetensi dan Motivasi Terhadap Kinerja

Tabel 4. Deskriptif Variabel Kompensasi

\begin{tabular}{cccc}
\hline Dimensi & Jumlah Skor & Skor maksimal & Persentase (\%) \\
\hline Pengetahuan & 23,62 & 32 & 73,81 \\
Keahlian & 26,68 & 36 & 74,10 \\
Sikap & 11,12 & 16 & 69,49 \\
Total & 61,41 & 84 & 73,11 \\
\hline
\end{tabular}

Sumber: Analisis Data Primer (2020)

Variabel kompetensi mempengaruhi kinerja karyawan PTPN IX Kebun Jollong Pati. Berdasarkan hasil analisis jalur diketahui variabel kompetensi mempengaruhi variabel inerja sebesar 19,2\%. Variabel kompetensi juga menjadi hal penting, karena kompetensi ada keterkaitannya terhadap produktivitas, kualitas dan kinerja (Edison, dkk 2016). Dalam analisis deskriptif, kompetensi yang dimiliki karyawan pemeliharaan kebun PTPN IX Kebun Jollong adalah cukup tinggi. Dimensi yang digunakan adalah pengetahuan, keahlian, dan sikap. Hal ini sejalan pernyataan dari Dwiyanti, dkk (2019) bahwa kompetensi secara positif berpengaruh terhadap kinerja karyawan. didukung dengan hasil penelitian Oktora, dkk (2018) yakni dengan diterapkannya kompetensi yang tepat maka dapat mengubah cara bekerja karyawan yaitu dari cara kerja yang manual menjadi automatically. Kecepatan dan ketepatan dalam bekerja pun dapat terlihat dengan jelas dan dapat disimpulkan bahwa variabel kompetensi mempunyai pengaruh terhadap kinerja karyawan.

\section{Motivasi}

Pada penelitian ini penulis membuat beberapa pertanyaan yang dibuat berdasarkan beberapa dimensi variabel kompetensi yaitu dimensi kebutuhan fisiologis, kebutuhan rasa aman, kebutuhan untuk disukai, kebutuhan harga diri, dan kebutuhan mengembangkan diri. Analisis yang digunakan untuk variabel motivasi adalah analisis deskriptif, yang bertujuan untuk mendeskripsikan persepsi responden yang diteliti dalam bentuk distribusi frekuensi dan persentase. Berikut kategori pada variabel kompensasi yang digunakan dalam penelitian ini. 
Jurnal Dinamika Sosial Ekonomi, 22 (1) : 33-45

Tabel 5. Kategori Variabel Motivasi

\begin{tabular}{ccc}
\hline Kategori & Skor & $\begin{array}{c}\text { Persentase } \\
(\boldsymbol{\%})\end{array}$ \\
\hline Rendah & $12,00-21,00$ & $25,00-43,75$ \\
Kurang Tinggi & $21,01-30,01$ & $43,76-62,51$ \\
Cukup Tinggi & $30,02-39,02$ & $62,52-81,27$ \\
Tinggi & $39,03-48,00$ & $81,28-100,00$ \\
\hline
\end{tabular}

Sumber: Analisis Data Primer (2020)

Tabel 6. Deskriptif Variabel Motivasi

\begin{tabular}{cccc}
\hline Dimensi & Jumlah Skor & Skor maksimal & Persentase (\%) \\
\hline Kebutuhan fisiologis & 5,88 & 8 & 73,53 \\
Kebutuhan rasa aman & 14.56 & 20 & 72,79 \\
kebutuhan untuk disukai & 5,59 & 8 & 69,85 \\
Kebutuhan harga diri & 6,15 & 8 & 76,84 \\
kebutuhan aktualisasi diri & 2,82 & 4 & 70,59 \\
Total & 35,00 & 48 & 72,92 \\
\hline
\end{tabular}

Sumber: Analisis Data Primer (2020)

Rata-rata persentase variabel motivasi pada analisis deskriptif termasuk dalam kategori cukup tinggi. Hal ini dapat dilihat dari tabel 6, yakni memiliki persentase sebesar 72,92 dimana termasuk dalam kategori cukup tinggi. Pada variabel motivasi, dimensi yang digunakan adalah fisiologis, kebutuhan rasa aman, kebutuhan untuk disukai, kebutuhan harga diri, dan kebutuhan pengembangan diri. Hal ini sejalan dengan penelitian Jufrizen (2017) yang menunjukkan bahwa semakin tinggi motivasi kerja akan mengakibatkan semakin tinggi pula kinerja. Hal ini didukung dengan hasil penelitian Rosmaini dan Tanjung (2019) bahwa motivasi berpengaruh terhadap kinerja karyawan. Seorang karyawan akan memiliki kinerja yang baik, apabila memiliki keinginan, harapan, kebutuhan, tujuan, sasaran, dorongan, dan insentif, sehingga dengan memotivasi maka dapat meningkatkan kinerja.

\section{Kinerja}

Pada penelitian ini analisis yang digunakan untuk mengetahui pengaruh langsung dan tidak langsung kompensasi kompetensi, dan motivasi terhadap kinerja 
Rangin, et.al, Pengaruh Kompensasi Kompetensi dan Motivasi Terhadap Kinerja

karyawan yaitu analisis jalur (pathway analysis). Untuk melakukan analisis jalur menggunakan langkah-langkah sebagai berikut (Riduwan dan Kuncoro, 2017):

a. Merumuskan hipotesis dan persamaan struktural

b. Menghitung koefisien jalur yang didasarkan pada koefisien regresi

c. Gambarkan diagram jalur lengkap

d. Menghitung koefisien regresi untuk struktur yang telah dirumuskan

e. Menghitung koefisien jalur secara simultan (keseluruhan)

1) Menghitung koefisien jalur secara parsial (individu)

2) Menghitung pengaruh langsung (direct effect), pengaruh tidak langsung (indirect effect), dan total pengaruh.

3) Meringkas dan menyimpulkan

Pengaruh antar variabel itu diwujudkan dalam bentuk diagram sebagai berikut:

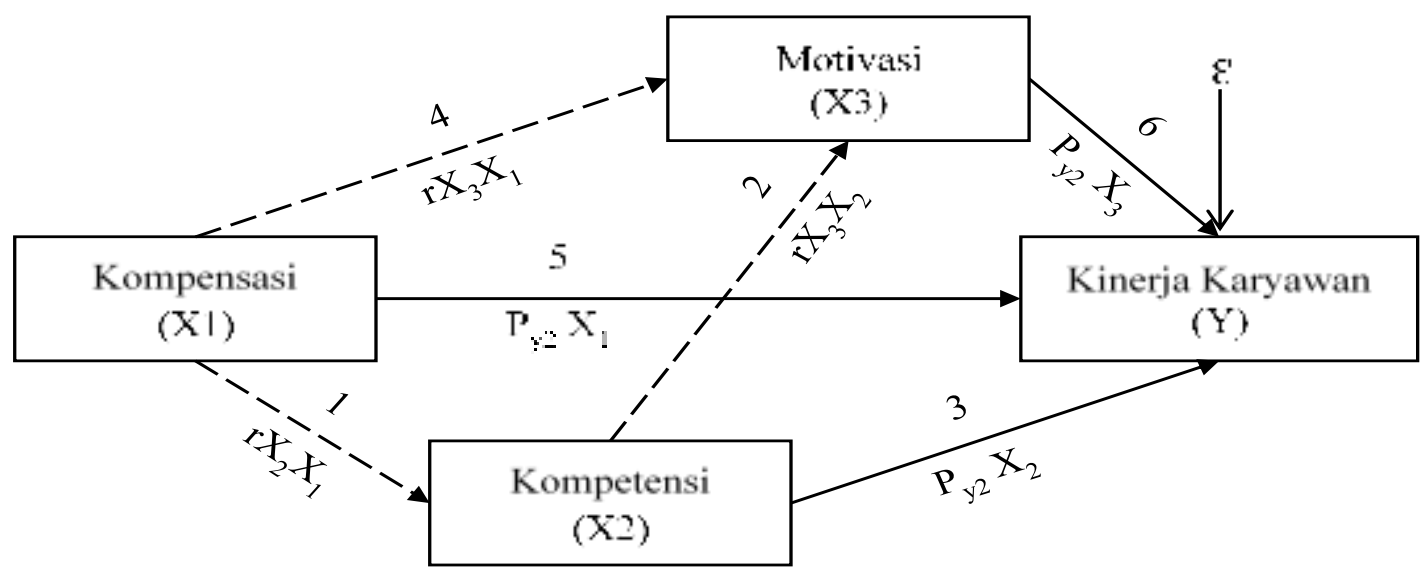

Keterangan:

Gambar I Diagram Jalur Antar Variabel



Sumber: Analisis Data Primer (2020)

Penelitian ini membahas mengenai kinerja karyawan dipengaruhi oleh kompensasi, kompetensi dan motivasi secara langsung dan tidak langsung. Berikut hasil analisis jalur hubungan variabel kompensasi, kompetensi, motivasi dan kinerja karyawan. 
Jurnal Dinamika Sosial Ekonomi, 22 (1) : 33-45

Tabel 7 Hasil Analisis Regresi

\begin{tabular}{lcrrrr}
\hline \multicolumn{1}{c}{ Model } & Model Summary & \multicolumn{3}{c}{ Coefficients } & Anova \\
& Adjusted $R$ Square & $\begin{array}{c}\text { Standardized } \\
\text { Coefficients } \\
\text { Beta }\end{array}$ & $\mathrm{t}$ & Sig, & \\
\hline (Constant) & & & $-3,666$ & $0,001^{* *}$ & $\mathrm{~F}=61,305$ \\
Kompensasi & 0,846 & 0,199 & 2,149 & $0,040^{*}$ & Sig $=0,000$ \\
Kompetensi & & 0,192 & 2,086 & $0,046^{*}$ & \\
Motivasi & & 0,643 & 5,652 & $0,000^{* *}$ & \\
\hline
\end{tabular}

Sumber: Analisis Data Primer (2020)
Keterangan:
$\begin{array}{ll}* * & =\text { signifikan pada alpha } 1 \% \\ * & =\text { signifikan pada alpha } 5 \% \\ \mathrm{~ns} \quad=\text { non signifikan }\end{array}$

Berdasarkan tabel 7, untuk mengetahui besar pengaruh pada regresi berganda dapat dengan melihat nilai Adjusted $R$ Square. Maka dapat diketahui bahwa variabel kompensasi, kompetensi, dan motivasi berpengaruh secara signifikan terhadap variabel kinerja sebesar $84,6 \%$, dan sisanya sebesar $15,4 \%$ dipengaruhi oleh faktor lain diluar model yang tidak diteliti oleh penulis.

Uji parsial digunakan untuk mengetahui pengaruh atau tidaknya masingmasing variabel bebas terhadap variabel terikat. Variabel kompensasi memiliki nilai signifikan 0,040 . Oleh karena itu nilai sig $<\alpha(0,05)$ maka, kompensasi secara individu mempengaruhi kinerja karyawan. Variabel kompetensi memiliki nilai signifikan 0,046 . Oleh karena itu nilai sig $<\alpha(0,05)$ maka, kompetensi secara individu mempengaruhi kinerja karyawan Variabel motivasi dengan memiliki nilai signifikan 0,000. Oleh karena itu nilai sig $<\alpha(0,01)$ maka, motivasi secara individu mempengaruhi kinerja karyawan.

Berdasarkan tabel 2 besar pengaruh langsung dari kompensasi terhadap kinerja adalah $(\rho y x 1)^{2}$ atau 0,040 Sedangkan besar tidak langsung kompensasi melalui kompetensi adalah $\rho Y X 1, r X 1 X 2, \rho Y X 2$ atau 0,016. Pengaruh tidak langsung variabel kompensasi terhadap variabel kinerja melalui variabel motivasi adalah $\rho Y X 1, \mathrm{rX} 1 \mathrm{X} 2, \rho \mathrm{YX} 3$ atau 0,086. Pada pengaruh langsung variabel kompetensi terhadap variabel kinerja adalah $(\rho y x 2)^{2}$ 0,037. Pengaruh tidak langsung kompetensi melalui motivasi adalah $\rho Y X 2, \mathrm{rX} 2 \mathrm{X} 3, \rho \mathrm{YX} 3$ atau 0,082. 
Rangin, et.al, Pengaruh Kompensasi Kompetensi dan Motivasi Terhadap Kinerja

Pada pengaruh langsung motivasi terhadap kinerja adalah $(\rho y x 3)^{2}$ atau 0,413 . Pengaruh total dapat diperoleh dari penjumlahan pengaruh langsung dan tidak langsung yaitu sebesar 0,674.

Tabel 8. Perhitungan Pengaruh Langsung dan Tidak Langsung

\begin{tabular}{cccc}
\hline Variabel & $\begin{array}{c}\text { Pengaruh } \\
\text { Langsung }\end{array}$ & $\begin{array}{c}\text { Pengaruh } \\
\text { Tidak } \\
\text { Langsung }\end{array}$ & $\begin{array}{c}\text { Total Pengaruh } \\
(\text { PL + PTL) }\end{array}$ \\
\hline Kompensasi (X1) & 0,040 & - & 0,040 \\
X1 melalui X2 & - & 0,016 & 0,016 \\
X1 melalui X3 & - & 0,086 & 0,086 \\
\hline Total & 0,040 & 0,102 & 0,142 \\
\hline Kompetensi (X2) & 0,283 & - & 0,283 \\
X2 melalui X3 & - & 0,082 & 0,082 \\
\hline Total & 0,283 & 0,082 & 0,119 \\
\hline Motivasi (X3) & 0,413 & - & 0,413 \\
\hline Total & 0,413 & - & 0,413 \\
\hline Total Keseluruhan & 0,490 & 0,184 & 0,674 \\
\hline
\end{tabular}

Sumber: Analisis Data Primer (2020)

Berdasarkan tabel 8 masing - masing variabel bebas memiliki pengaruh langsung dan berkontribusi terhadap kinerja. Pertama setiap kenaikan satu satuan variabel kinerja maka variabel kompensasi menunjukan kontribusi terhadap kinerja sebesar 0199 satuan dan pengaruh tersebut signifikan (Sig. 0,040 < 0,05). Kedua, setiap kenaikan satu satuan variabel kinerja maka variabel kompetensi menunjukan kontribusi terhadap kinerja sebesar 192 satuan dan pengaruh tersebut signifikan (Sig. 0,046 < 0,05). Ketiga, setiap kenaikan satu satuan variabel kinerja maka variabel motivasi menunjukan kontribusi sebesar 0,643 satuan dan signifikan (Sig. 0,000<0,05).

\section{SIMPULAN}

Kompensasi, kompetensi, motivasi, dan kinerja pada karyawan bagian pemeliharaan kebun PTPN IX Kebun Jollong Pati termasuk dalam kategori cukup tinggi.Kinerja dipengaruhi kompensasi, kompetensi, dan motivasi secara langsung dan tidak langsung. Total pengaruh langsung dan tidak langsung sebesar 0,674 
Jurnal Dinamika Sosial Ekonomi, 22 (1) : 33-45

dimana terdiri dari total pengaruh langsung sebesar 0,490 dan pengaruh secara tidak langsung sebesar 0,184 .

Pada variabel kompensasi, sebaiknya karyawan yang menggunakan kendaraan pribadi diberi sedikit tambahan uang apabila kendaraan yang digunakan rusak ketika sedang bekerja sehingga karyawan yang menggunakan kendaraan pribadi tidak mengeluarkan uang berlebih untuk servis kendaraannya. Pada variabel kompetensi, sebaiknya para pimpinan lebih memilih untuk memberikan perhatian yang sama rata kepada para karyawan agar nantinya tidak menyebabkan kecemburuan antar karyawan dan untuk menciptakan suasana kerja yang lebih baik sehingga nantinya dapat meningkatkan motivasi kerja karyawan. Pada variabel motivasi, sebaiknya pimpinan perlu mendorong karyawan untuk melakukan inisiatif agar saling membantu antar karyawan dalam melakukan pekerjaan sehingga pekerjaan lebih cepat terselesaikan. Dorongan tersebut dapat berupa apresiasi atau penilaian yang nantinya penilaian tersebut untuk diakumulasi dalam pemberian penghargaan sebagai karyawan terbaik. Pada kinerja, sebaiknya PTPN IX Kebun Jollong melakukan perekrutan tenaga kerja yang lebih muda agar pengerjaan tugas dapat maksimal. Selain itu karyawan yang lebih muda juga akan lebih cepat menyerap ilmu ketika dilakukan pelatihan karyawan. Dengan adanya tenaga kerja yang sudah ada ditambah dengan tenaga kerja yang lebih muda, maka akan lebih mudah perusahaan untuk mencapai targetnya.

\section{DAFTAR PUSTAKA}

Dessler, Gary. (2009). Manajemen Sumber Daya Manusia Ed. 10. Jakarta: PT Indeks.

Dwijayanti, Ni Kadek Ayu Dwiyanti, dan Heryanda K. (2017). Pengaruh Kompetensi Dan Motivasi Kerja Terhadap Kinerja Karyawan. Jurnal Manajemen Indonesia 5 (127): 6.

Edison, Emron, Yohny Anwar, dan Imas Komariyah. (2016). Manajemen Sumber Daya Manusia: Strategi dan Perubahan dalam Rangka Meningkatkan Kinerja Pegawai dan Organisasi. Bandung: Alfabeta. 
Rangin, et.al, Pengaruh Kompensasi Kompetensi dan Motivasi Terhadap Kinerja

Fikri, K. dan Apriansyah R. (2018). Pengaruh Kompensasi Terhadap Kinerja Karyawan Yang Dimediasi Oleh Kepuasan Kerja Pada CV. Pelita Mandiri V Pematang Reba. Jurnal Manajemen dan Bisnis 7(1):23-32.

Jufrizen, J. (2017). Pengaruh kemampuan dan motivasi terhadap kinerja perawat: Studi pada Rumah Sakit Umum Madani Medan. Jurnal Riset Sains Manajemen.1 (1): 27-34.

Nugraha, Alvi dan Tjahwati, S. (2017). Pengaruh Kompensasi Terhadap Kinerja Karyawan. Jurnal Riset Bisnis dan Investasi. 3 (31): 3-4.

Oktora, Jublina dan Rizan, M. (2018). Pengaruh Gaya Kepemimpinan Transaksional Dan Transformasional, Motivasi Serta Kompetensi Terhadap Kinerja Karyawan Pt. Sanjayatama Lestari. Jurnal Dinamika Manajemen dan Bisnis. 1 (59): 1-2.

Priyono. (2007). Pengantar Manajemen. Surabaya: Zifatama.

Riduwan dan Kuncoro. (2017). Cara Menggunakan dan Memaknai Path Analysis. (Analisis Jalur). Bandung: Alfabeta.

Rosmaini dan Tanjung, H. (2019). Pengaruh Kompetensi, Motivasi dan Kepuasan Kerja Terhadap Kinerja Pegawai. Jurnal Ilmiah Magister Manajemen. 2 (11): 1 . 